\title{
Exploring the role of medicinal plant-based immunomodulators for effective therapy of leishmaniasis
}

\section{Garima Chouhan ${ }^{1}$, Mohammad Islamuddin ${ }^{1}$, Dinkar Sahal ${ }^{2}$ and Farhat Afrin ${ }^{1}$ *}

1 Parasite Immunology Laboratory, Department of Biotechnology, Jamia Hamdard (Hamdard University), New Delhi, India

${ }^{2}$ Malaria Group, International Centre for Genetic Engineering and Biotechnology, New Delhi, India

\section{Edited by:}

Nahid Ali, Indian Institute of Chemical

Biology, India

Reviewed by:

Ennio De Gregorio, Novartis Vaccines and Diagnostics, Italy

Angamuthu Selvapandiyan, Institute

of Molecular Medicine, India

${ }^{*}$ Correspondence:

Farhat Afrin, Parasite Immunology

Laboratory, Department of

Biotechnology, Jamia Hamdard

(Hamdard University), New Delhi

110062, India

e-mail:afrin_farhat@yahoo.co.in
Leishmaniasis is a pestilent affliction that importunately needs better therapeutics necessitated by the absence of effective vaccine, emergence as HIV co-infection, and the dread of debilitating chemotherapy. The Leishmania parasites incapacitate host macrophages by preventing the formation of phagolysosomes, impeding antigen presentation to $T$ cells, leading to suppression of cell-mediated immunity. An ideal approach to cure leishmaniasis includes administration of antileishmanial compounds that can concomitantly establish an effective Th1 response via restoration of requisite signaling between macrophages and T cells, for subsequent activation of macrophages to eliminate intracellular amastigotes. Plants have provided an opulent treasure of biomolecules that have fueled the discovery of antileishmanial drugs. Modulation of immune functions using medicinal plants and their products has emerged as an effective therapeutic strategy. Herein, we review the plant extracts and natural products that have resulted in therapeutic polarization of host immunity to cure leishmaniasis. These immunostimulatory phytochemicals as source of potential antileishmanials may provide new strategies to combat leishmaniasis, alone or as adjunct modality.

Keywords: medicinal plants, immunomodulators, leishmaniasis, antileishmanial, phytochemicals

\section{INTRODUCTION}

Leishmaniasis is a neglected; usually poverty-associated complex vector-borne disease that is caused by more than 21 species of parasites belonging to the order Kinetoplastida and family Trypanosomatidae. The disease manifests into different clinical indexes depending on the parasite tropism and ranges from selfhealing cutaneous lesions, to malign mucocutaneous leishmaniasis and fatal visceral manifestations. The disease is endemic in 98 countries, where 10-12 million people are afflicted worldwide with 1.5-2.5 million new cases, death toll of 70,000 and 350 million at risk of developing the infection (1-3). Since Leishmania parasites reside and multiply within the parasitophorous vacuoles of macrophages, failure of host immunity to contain the infection results in immunosuppression. Thus, the host becomes susceptible to various secondary infections including $\operatorname{HIV}(4,5)$.

The antiquated therapeutic modalities for leishmaniasis are crippled because of variable efficacy, drug resistance, and pronounced side effects. Even the known antileishmanial drugs such as amphotericin B (AmB), sodium stibogluconate (SSG), and miltefosine exert their antileishmanial effect via host immunomodulation [(6) and references therein]. Modulation of the host immune response via generation of antileishmanial vaccine would certainly be a propitious step in leishmaniasis control, but is impeded by the digenetic life cycle of Leishmania, and antigenic diversity among different Leishmania species, making prospects of a cross-protective vaccine a distant future $(7,8)$. Thus, in the absence of any vaccine, a quintessential approach to control leishmaniasis shall be based on discovery of drugs from alternative sources that can directly kill the parasite as well as activate sentinels of immune system for clearance of the pathogen. Herein, we further elaborate the mechanisms employed by Leishmania parasites to evade host immune responses, lacunae in current chemotherapy and discuss potential role of natural immunomodulators in antileishmanial therapy.

\section{LEISHMANIA PARASITE-EVASION FROM HOST IMMUNE DEFENSES \\ MODULATION OF NEUTROPHIL FUNCTIONS}

Within $24 \mathrm{~h}$ of Leishmania infection, neutrophils are recruited to the site of infection, serving as early and transitory host to Leishmania promastigotes (9). Although exact mechanisms underlying the recruitment of neutrophils remain unclear, the role of both parasites or vector-derived molecules is speculated $(9,10)$. The role of neutrophils in Leishmania infection is variable, Leishmania species specific, and also depends on the host genetics (11-14). Although neutrophils are responsible for early containment of different Leishmania species (15-18), they play equally pivotal role in harboring the parasites till they reach their evolutionary destined host cells, i.e., macrophages. Leishmania promastigotes deviously modulate neutrophil phagocytic functions in more than one way. Internalized Leishmania promastigotes block the production of CXC-chemokine interferon gamma (IFN- $\gamma$ ) inducible protein-10, which results in decreased recruitment and activation of natural killer (NK) cells and Th1 cells (10). Leishmania donovani promastigotes have been shown to induce NETs (fibrous traps of DNA, histones, and proteins) in which they get trapped but escape their microbicidal activity by aid of lipophosphogylcan (LPG) (19). Leishmania parasites also extend the life span 
of neutrophils and delay their apoptosis by various mechanisms $(20,21)$. Since ingestion of apoptotic neutrophils by macrophages does not trigger macrophage microbicidal defenses, it creates safe passage for stealth entry of Leishmania parasites. The theory that neutrophils act as Trojan horses is well perceived in case of L. donovani $(10,22)$, but there is also evidence that Leishmania parasites escape neutrophils before infecting the macrophages (23), a Trojan rabbit strategy where viable promastigotes hide in the shadow of apoptotic neutrophils (9).

\section{ENTRY INTO MACROPHAGES}

In their quest for survival, Leishmania parasites face the arduous challenge to gain entry inside the macrophages and silence their impeccable defenses. The parasites express a wide array of ligands on their surfaces, which interact with a variety of macrophage receptors. Some of the key receptors that mediate promastigote-macrophage binding include the receptors for complement, fibronectin, mannose-fucose, and other sugars [(24) and references therein]. Interestingly, the foremost ligands employed by parasite for its phagocytic uptake are not encoded by the parasite itself; instead, parasite gets ingested into the macrophages via opsonin-dependent pathways. The sharp-witted Leishmania parasites not only circumvent complement-mediated lysis but also modulate the complement system for their active uptake inside the macrophages. $\mathrm{C} 3 \mathrm{bi}$ and $\mathrm{C} 3 \mathrm{~b}$ are two major complement system components that bind to promastigote surface (25-28) and facilitate their intracellular uptake via CR3 and CR1, respectively. The uptake via CR3 is more advantageous since internalization via these receptors does not result in oxidative burst and also suppresses the secretion of IL-12 and other pro-inflammatory signals, thus hampering the initiation of cell-mediated immunity (CMI) $(29,30)$.

\section{ESTABLISHING INFECTION IN MACROPHAGES}

Once inside the macrophage phagosomes, promastigotes create an intracellular niche for their survival by silencing the macrophages through multifarious schemes. Predominantly, Leishmania parasites retard phagosome maturation, delay enodosome-phagosome fusion, inhibit hydrolytic enzymes in phagolysosomes, prevent generation of reactive-nitrogen and -oxygen species, suppress antigen presentation, and repress pro-inflammatory cytokine production. LPG present on the surface of Leishmania parasites retards phagosome maturation by inducing Cdc42- and Rac1 (Rho family GTPases, F-actin regulators)-dependent F-actin accumulation, which also involves inhibition of PKC $\alpha$ leading to impaired recruitment of LAMP-1 and rab7 (31-34). It has been reported earlier that incorporation of LPG selectively into one of the leaflets of lipid bilayers of phagosome membrane alters its biophysical properties making it less fusogenic [(31) and references therein]. LPG impairs the acquisition of vesicular proton-ATPase, which is involved in acidification of phagolysosomes (35). Leishmania parasites either decimate or suppress expression of major histocompatibility complex (36-38). Leishmania parasites also interfere with protein expression of their host cells (39), suppress the secretion of pro-inflammatory cytokines (IFN- $\gamma$, TNF- $\alpha$, IL-6, IL-12), and induce secretion of anti-inflammatory cytokines (IL-4, IL10 , and TGF- $\beta$ ) via modulation of host cell signaling (40-42).
Thus, establishment of Leishmania infection involves complex in-depth interactions between a vast repertoire of immunostimulating and immunosuppressive molecules that finally determine a species-dependent outcome of infection.

\section{THERAPEUTIC MODALITIES}

The pentavalent antimonials, SSG and Meglumine Antimoniate (MA), have been employed in treatment of visceral leishmaniasis (VL) and cutaneous leishmaniasis (CL) for more than 60 years. The use of SSG and MA as first-line treatment for VL has been already abandoned after failure rates of $\sim 65 \%$ in endemic regions of Bihar, India. Antimonials show variable efficacy against CL and VL, and accompanying severe side effects have demerited their use. The second line of drug AmB is now employed to treat the antimony-resistant patients but the need of hospitalization, prolonged duration of treatment, and infusion-related side effects are drawbacks. These constraints have now been overcome by lipid formulations of $\mathrm{AmB}$ that prevent tissue retention, thereby reducing the toxicity and promoting preferential uptake by reticuloendothelial cells that harbor the parasites. However, cost of liposomal AmB is a serious limitation and frequent noxious effects and drug resistance associated with pentamidine has also led to its withdrawal. Paromomycin has been registered for use in India against VL but is oto- and nephrotoxic. Miltefosine, the first oral drug, is of limited use because of its teratogenicity (43-45).

\section{NATURAL IMMUNOMODULATORS: ROLE IN ANTILEISHMANIAL THERAPY}

The drug discovery against leishmaniasis has been more reliant on therapeutic switching rather than discovery of novel drugs. Since elevation of host immunity is critical in parallel to the drug-mediated killing of Leishmania parasites, the antileishmanial arsenal may be benefited by antileishmanials that can prong a bifurcated attack, i.e., elimination of the parasites as well as restoration of CMI. The potential of immunomodulators in treating experimental leishmaniasis gained momentum with the discovery of antileishmanial activity of imiquimod $(46,47)$, an agonist for toll-like receptor 7, which is present on macrophages and dendritic cells (DC) and promotes the development of Th1 immune response [(48) and references therein]. Several other synthetic compounds such as $\mathrm{S}_{2}$ complex (an organic complex of copper chloride, ascorbic acid, and nicotinamide) (49), acetyl salicylic acid (50), and immunomodulatory peptide from cystatin (51) have been demonstrated to possess dual immune-modulating and antileishmanial activities.

Various herbal formulations and plant secondary metabolites such as flavonoids, isoflavonoids, saponins, alkaloids, sesquiterpenes, polysaccharides, tannins, indoles, and glucans are known to be immunomodulatory in different diseases $(52,53)$. Among natural resources, plants have been most extensively explored for bioactive leishmanicidal and immunomodulatory compounds. Plant extracts contain a plethora of biomolecules that can naturally kill Leishmania parasites and also exert immunostimulatory properties, on otherwise depressed immune system during the diseased state, as has been extensively reviewed in Table $\mathbf{1}$.

In brief, the studies examining immunomodulatory effect of bioactive plant extracts or compounds have reported skewing of 
Table 1 | Immunomodulatory antileishmanial plant extracts or purified molecules thereof.

\begin{tabular}{|c|c|c|c|c|}
\hline $\begin{array}{l}\text { Plant extracts/purified } \\
\text { compounds/secondary } \\
\text { metabolites/herbal medicines }\end{array}$ & $\begin{array}{l}\text { Leishmania } \\
\text { strain }\end{array}$ & $\begin{array}{l}\text { Concentration (in vitro)/dose } \\
\text { regimen (in vivo) }\end{array}$ & $\begin{array}{l}\text { Immunomodulatory } \\
\text { mechanism }\end{array}$ & Reference \\
\hline $\begin{array}{l}\text { Galactomannan (isolated from } \\
\text { seeds of Mimosa scabrella) }\end{array}$ & $\begin{array}{l}\text { Leishmania } \\
\text { amazonensis (MHOM/ } \\
\text { BR173/M2269) }\end{array}$ & $250 \mu \mathrm{g} / \mathrm{ml}$ & $\begin{array}{l}\uparrow I L-1 \beta, I L-6 \text { and NO production } \\
\text { TNF- } \alpha \text { and IL-10 levels unaffected }\end{array}$ & $\begin{array}{l}\text { Adriazola et al. } \\
\text { (56) }\end{array}$ \\
\hline $\begin{array}{l}\text { Niranthrin (lignan isolated from } \\
\text { aerial parts of Phyllanthus } \\
\text { amarus) }\end{array}$ & $\begin{array}{l}\text { L. donovani } \\
\text { (MHOM/IN/1983/ } \\
\text { AG83) }\end{array}$ & $\begin{array}{l}\mathrm{b}_{5} \text { and } 10 \mathrm{mg} / \mathrm{kg} \text { b.w. twice for } \\
3 \text { weeks }\end{array}$ & $\begin{array}{l}\uparrow N O, R O S, \text { iNOS } \\
\text { Induced lymphoproliferation } \\
\uparrow I F N-\gamma \text {, TNF- } \alpha \text {, and IL-12p70 } \\
\uparrow \text { IgG2a levels } \\
\downarrow I L-10 \text { and TGF- } \beta \\
\text { No change in IL-4 expression and IgG1 }\end{array}$ & $\begin{array}{l}\text { Chowdhury } \\
\text { et al. (58) }\end{array}$ \\
\hline $\begin{array}{l}\text { aberberine chloride (quaternary } \\
\text { isoquinoline alkaloid) }\end{array}$ & $\begin{array}{l}\text { L. donovani isolate } \\
\text { (NS2) }\end{array}$ & 2.5 and $10 \mu \mathrm{M}$ & $\begin{array}{l}\uparrow \text { NO production } \\
\text { Activated iNOS } \\
\uparrow \text { mRNA expression of IL-12p40 } \\
\downarrow \text { IL-10 } \\
\text { Upregulated p38 MAPK pathway }\end{array}$ & Saha et al. (59) \\
\hline $\begin{array}{l}\text { Echium amoenum } \\
\text { (flowers-aqueous and alcoholic } \\
\text { extracts) }\end{array}$ & $\begin{array}{l}\text { L. major } \\
(\mathrm{MRHO} / \mathrm{R} / 75 / \mathrm{ER})\end{array}$ & b 250,750 , and $3750 \mathrm{mg} / \mathrm{kg}$ b.w. & $\begin{array}{l}\uparrow \text { IFN- } \gamma \\
\text { Induced lymphoproliferation } \\
\text { IL-4 levels unaffected }\end{array}$ & $\begin{array}{l}\text { Hosseini and } \\
\text { Abolhassani } \\
\text { (62) }\end{array}$ \\
\hline A. sativum (aqueous extract) & $\begin{array}{l}\text { L. major } \\
(\mathrm{MRHO} / \mathrm{R} / 75 / \mathrm{ER})\end{array}$ & $37 \mathrm{mg} / \mathrm{ml}$ & $\begin{array}{l}\uparrow I N F-\gamma \text { and iNOS mRNA expression } \\
\text { levels }\end{array}$ & $\begin{array}{l}\text { Gharavi et al. } \\
\text { (63) }\end{array}$ \\
\hline A.sativum (aqueous extract) & $\begin{array}{l}\text { L. major } \\
(\mathrm{MRHO} / \mathrm{R} / 75 / \mathrm{ER})\end{array}$ & $37 \mathrm{mg} / \mathrm{ml}$ & $\begin{array}{l}\uparrow I L-12 \\
\downarrow \mid L-10\end{array}$ & $\begin{array}{l}\text { Gharavi et al. } \\
\text { (64) }\end{array}$ \\
\hline $\begin{array}{l}\text { aArtemisinin (sesquiterpene } \\
\text { lactone from Artemisia annua) }\end{array}$ & L. donovani & $\begin{array}{l}10 \text { and } 25 \mu \mathrm{M} \\
\mathrm{b} 10 \text { and } 25 \mathrm{mg} / \mathrm{kg} \text { b.w. }\end{array}$ & $\begin{array}{l}\uparrow N O \text { production } \\
\uparrow I L-12 \text { and IFN- } \gamma\end{array}$ & Sen et al. (65) \\
\hline $\begin{array}{l}\text { Kalanchoe pinnata } \\
\text { (leaves-aqueous extract) }\end{array}$ & Leishmania chagasi & $\begin{array}{l}{ }^{\mathrm{b}} 400 \mathrm{mg} / \mathrm{kg} \text { b.w. by intragastric } \\
\text { gavage from day } 1-29 \text { of } \\
\text { infection }\end{array}$ & $\begin{array}{l}\text { Depressed serum IgG levels } \\
\downarrow I \mathrm{IL}-4 \text {, INF- } \gamma \\
\uparrow N O \text { production }\end{array}$ & $\begin{array}{l}\text { Gomes et al. } \\
(66)\end{array}$ \\
\hline
\end{tabular}


Table 1 | Continued

\begin{tabular}{|c|c|c|c|c|}
\hline $\begin{array}{l}\text { Plant extracts/purified } \\
\text { compounds/secondary } \\
\text { metabolites/herbal medicines }\end{array}$ & $\begin{array}{l}\text { Leishmania } \\
\text { strain }\end{array}$ & $\begin{array}{l}\text { Concentration (in vitro)/dose } \\
\text { regimen (in vivo) }\end{array}$ & $\begin{array}{l}\text { Immunomodulatory } \\
\text { mechanism }\end{array}$ & Reference \\
\hline $\begin{array}{l}\text { Warburgia ugandensis, Psiadia } \\
\text { punctulata, and Chasmanthera } \\
\text { dependens (bark-aqueous } \\
\text { extract) }\end{array}$ & $\begin{array}{l}\text { L. major } \\
(\text { IDU/KE/83 = NLB- } \\
\text { 144) }\end{array}$ & $1000 \mu \mathrm{g} / \mathrm{ml}$ & $\uparrow N O$ production & $\begin{array}{l}\text { Githinji et al. } \\
\text { (67) }\end{array}$ \\
\hline Himatanthus sucuuba latex & $\begin{array}{l}\text { L. amazonensis } \\
\text { (WHOM/BR/75/Josefa } \\
\text { strain) }\end{array}$ & $200 \mu \mathrm{g} / \mathrm{ml}$ & $\begin{array}{l}\uparrow \mathrm{TNF}-\alpha \text { and NO production } \\
\downarrow \mathrm{TGF}-\beta\end{array}$ & $\begin{array}{l}\text { Soares et al. } \\
(68)\end{array}$ \\
\hline A.sativum (methanolic extract) & L. donovani (NLB065) & $250 \mu \mathrm{g} / \mathrm{ml}$ & $\uparrow N O$ production & $\begin{array}{l}\text { Wabwoba } \\
\text { et al. (69) }\end{array}$ \\
\hline $\begin{array}{l}\text { Xylopia discreta (leaf methanolic } \\
\text { extract and essential oil) }\end{array}$ & $\begin{array}{l}\text { L. panamensis } \\
\text { (MHOM/CO/87/UA140) }\end{array}$ & Different concentrations & $\begin{array}{l}\uparrow \text { Monocyte chemoattractant protein-1 } \\
\text { (MCP-1) expression }\end{array}$ & $\begin{array}{l}\text { López et al. } \\
\text { (70) }\end{array}$ \\
\hline $\begin{array}{l}\text { a Quassin (one of the quassinoids } \\
\text { isolated from Quassia amara) }\end{array}$ & $\begin{array}{l}\text { L. donovani } \\
\text { (MHOM/IN/1983/AG83) }\end{array}$ & $25 \mu \mathrm{g} / \mathrm{ml}$ & $\begin{array}{l}\uparrow \text { iNOS2 expression } \\
\uparrow \mathrm{TNF}-\alpha \text {, and IL-12p70 } \\
\downarrow \mathrm{TGF}-\beta \text { and IL-10 }\end{array}$ & $\begin{array}{l}\text { Bhattacharjee } \\
\text { et al. (71) }\end{array}$ \\
\hline A.sativum (aqueous extract) & $\begin{array}{l}\text { Leishmania mexicana } \\
\text { (MNYC/BZ/62/M379) }\end{array}$ & $\begin{array}{l}37 \mu \mathrm{g} / \mathrm{ml} \\
\mathrm{b}_{2} 20 \text { and } 60 \mathrm{mg} / \mathrm{kg} \text { b.w. for } \\
2 \text { weeks i.p. }\end{array}$ & $\begin{array}{l}\uparrow \text { NO production } \\
\uparrow \text { IFN- } \gamma\end{array}$ & $\begin{array}{l}\text { Gamboa-León } \\
\text { et al. (72) }\end{array}$ \\
\hline $\begin{array}{l}\text { Pelargonium sidoides } \\
\text { (aqueous-ethanolic formulation } \\
\text { of roots and methanol insoluble } \\
\text { fraction of this extract) }\end{array}$ & L. major & $50 \mu \mathrm{g} / \mathrm{ml}$ & $\begin{array}{l}\uparrow \text { iNOS activity } \\
\uparrow \text { IFN- } \gamma, \text { IL-12, IL-18 mRNA levels }\end{array}$ & Trun et al. (73) \\
\hline $\begin{array}{l}\text { aPlant polyphenols (Tannins and } \\
\text { structurally related compounds) }\end{array}$ & $\begin{array}{l}\text { L. major and } \\
\text { L. donovani } \\
\text { promastigotes }\end{array}$ & Different concentrations & $\begin{array}{l}\text { Moderate effect on NO production } \\
\uparrow T N F \text { and INF like activities }\end{array}$ & $\begin{array}{l}\text { Kolodziej and } \\
\text { Kiderlen (74) }\end{array}$ \\
\hline $\begin{array}{l}\text { Desmodium gangeticum } \\
\text { (Aminoglucosyl glycerolipid and } \\
\text { Cerebroside) }\end{array}$ & L. donovani & $100 \mu \mathrm{g} / \mathrm{ml}$ & $\uparrow$ NO production & $\begin{array}{l}\text { Mishra et al. } \\
\text { (75) }\end{array}$ \\
\hline $\begin{array}{l}\text { Canova medication (Aconitum } \\
\text { napellus, Arsenium album, } \\
\text { Bryonia alba, and Thuya } \\
\text { occidentalis) }\end{array}$ & $\begin{array}{l}\text { L. amazonensis } \\
\text { (MHOM/BR/73/M2269) }\end{array}$ & 20 and $40 \%$ & $\uparrow N O$ production & $\begin{array}{l}\text { Pereira et al. } \\
(76)\end{array}$ \\
\hline Croton cajucara (Essential oil) & $\begin{array}{l}\text { L. amazonensis } \\
\text { (Raimundo strain, } \\
\text { MHOM/BR/76/Ma-5) }\end{array}$ & $1,1.5$, and $0.2 \mathrm{ng} / \mathrm{ml}$ & $\uparrow N O$ production & $\begin{array}{l}\text { do Socorro } \\
\text { et al. (77) }\end{array}$ \\
\hline A.sativum extract & $\begin{array}{l}\text { L. major } \\
\text { (MRHO/IR/76/ER) }\end{array}$ & 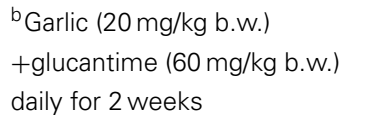 & $\begin{array}{l}\uparrow I F N-\gamma \text { and IL-2 } \\
\downarrow \mid L-4 \text { and IL-10 }\end{array}$ & $\begin{array}{l}\text { Ghazanfari } \\
\text { et al. (78) }\end{array}$ \\
\hline
\end{tabular}

a Synthetic molecules of plant origin.

${ }^{b}$ Studies carried out in BALB/C mice.

immune response from Th2 (diseased state) to Th1 (cure) by causing the up- or downregulation of pro-inflammatory (activating Th1) and anti-inflammatory (promoting Th2) cytokines, respectively. The most commonly assessed immunomodulatory parameter for parasite clearance is stimulation of nitric oxide
(NO). NO is the principle effector molecule in killing of Leishmania amastigotes (79) and is either estimated directly as nitrite concentration in culture supernatant or indirectly by the changes in nitric oxide synthase (iNOS) gene expression levels. NO-mediated killing of Leishmania parasites by tannins and related compounds 
has also been demonstrated (74). IL-12 is the central cytokine produced by DC, NK, and T cells, which activates macrophages to produce IFN- $\gamma$ and TNF- $\alpha$. Different plant secondary metabolites and extracts have induced IL-12 up-regulation (Table 1), indicating the worthy potential of natural resources. Macrophages also produce IL-18, which in synergism with IL-12 stimulates IFN$\gamma$ production and aids in parasite clearance $(80,81)$. Pelargonium sidoides extracts have been shown to increase mRNA levels of IL-18 in Leishmania major infection (73).

In parallel to stimulation of IL-12 and other pro-inflammatory cytokines, expression levels of IL-4, IL-10, and TGF- $\beta$ have also been widely investigated (Table 1). IL-4, IL-10, and TGF- $\beta$ inhibit the production of IFN- $\gamma$ from macrophages. IL- 4 is known to potently inhibit macrophage activation, but IL-10 plays a cardinal role in progression of both CL and VL. In both, murine and human VL, despite the production of adequate amounts of IFN- $\gamma$, the hosts are unable to mount an effective CMI response, and this host inefficiency is attributed to increased levels of IL10. Kane and Mosser (82) demonstrated that host-derived IgG present on Leishmania amastigotes ligates to $\mathrm{Fc} \gamma$ receptors on inflammatory macrophages and modulates them to secrete IL-10 in high amounts in CL. The levels of these Th 2 cytokines have been observed to decline along with successful recuperation of CMI after treatment with immunomodulatory extracts and molecules of natural origin (Table $\mathbf{1}$ ).

It can thus be well established that natural immunomodulators can skew the Th1-Th2 balance but pro- and anti-inflammatory cytokines play diverse and inter-regulatory roles. As also supported by Couper et al. (83), understanding the dynamics of Th1-Th2 paradigm has changed over the years and it is conceived that both Th1 and Th2 cells can mediate inflammation as well as aid parasite clearance. For instance, Néris et al. (57) reported that Licarin A, treated L. major-infected macrophages exhibit decline in IL-6 as well as IL-10 levels. IL- 6 is a characteristic pro-inflammatory cytokine, which also negatively regulates Th1 differentiation and promotes $\mathrm{CD}^{+}{ }^{+}$Th2 differentiation mediated by IL-4 (84). However, as the study presented only the in vitro data, and also the proor anti-immunopotentiating effect can be dose dependent (85) further in vivo studies may throw proper light on mechanism of action of Licarin A.

\section{CONCLUSION}

The use of herbal preparations to modulate the immune response to cure or avert diseases has been described in traditional systems of Indian, Unani, and Chinese medicine. The natural substances with dual, antileishmanial, and immunomodulatory properties have been carefully evaluated, however, it should be noted that human leishmaniasis varies in immunological pattern from murine leishmaniasis. Thus, the natural immunomodulators need to be evaluated more systematically and specifically in terms of dosage, biodistribution, kinetics, and interactions with other drugs and their putative role in other co-infections should also be examined.

Nonetheless, the concept of using natural immunomodulators to treat parasitic infections including leishmaniasis holds mighty potential in achieving the control of this disease. These natural immunomodulatory molecules can serve as scaffolds for synthesis and discovery of new immunodrugs. Also, the use of natural immunomodulators in synergy with existing drugs may involve the functional manipulation of multiple molecular targets leading to improved therapeutic efficacy and reduced toxicity.

\section{ACKNOWLEDGMENTS}

This work received financial assistance from University Grants Commission (UGC), Indian Council of Medical Research (ICMR), and Department of Biotechnology, Government of India. Garima Chouhan and Mohammad Islamuddin are recipients of UGCBSR (Basic Science Research) and ICMR-SRF (Senior Research Fellowship), respectively.

\section{REFERENCES}

1. Alvar J, Velez ID, Bern C, Herrero M, Desjeux P, Cano J, et al. Leishmaniasis worldwide and global estimates of its incidence. PLoS One (2012) 7:e35671. doi:10.1371/journal.pone.0035671

2. Sharlow ER, Grogl M, Johnson J, Lazo JS. Anti-leishmanial drug discovery: rising to the challenges of a highly neglected disease. Mol Interv (2010) 10:72-5. doi:10.1124/mi.10.2.4

3. Bern C, Courtenay O, Alvar J. Of cattle, sandflies and men: a systematic review of risk factor analyses for South Asian visceral leishmaniasis and implications for elimination. PLoS Negl Trop Dis (2010) 4:e599. doi:10.1371/journal.pntd. 0000599

4. Cota GF, de Sousa MR, Rabello A. Predictors of visceral leishmaniasis relapse in HIV-infected patients: a systematic review. PLoS Negl Trop Dis (2011) 5:e1153. doi:10.1371/journal.pntd.0001153

5. Kumar R, Nylén S. Immunobiology of visceral leishmaniasis. Front Immunol (2012) 3:251. doi:10.3389/fimmu.2012.00251

6. Saha P, Mukhopadhyay D, Chatterjee M. Immunomodulation by chemotherapeutics agents against Leishmaniasis. Int Immunopharmacol (2011) 11:1668-79. doi:10.1016/j.intimp.2011.08.002

7. Kedzierski L. Leishmaniasis vaccine: where are we today? J Glob Infect Dis (2010) 2:177-85. doi:10.4103/0974-777X.62881

8. Schallig HD, Oskam L. Review: molecular biological applications in the diagnosis and control of leishmaniasis and parasite identification. Trop Med Int Health (2002) 7:641-51. doi:10.1046/j.1365-3156.2002.00911.x

9. Ritter U, Frischknecht F, van Zandbergen G. Are neutrophils important host cells for Leishmania parasites? Trends Parasitol (2009) 25:505-10. doi:10.1016/j. pt.2009.08.003

10. van Zandbergen G, Hermann N, Laufs H, Solbach W, Laskay T. Leishmania promastigotes release a granulocyte chemotactic factor and induce interleukin-8 release but inhibit interferon-inducible 10 production by neutrophil granulocytes. Infect Immun (2002) 70:4177-84. doi:10.1128/IAI.70.8.4177-4184.2002

11. Chen L, Zhang ZH, Watanabe T, Yamashita T, Kobayakawa T, Kaneko A, et al. The involvement of neutrophils in the resistance to Leishmania major infection in susceptible but not in resistance mice. Parasitol Int (2005) 54:109-18. doi:10.1016/j.parint.2005.02.001

12. Lima GM, Vallochi AL, Silva UR, Bevilacqua EM, Kiffer MM, Abrahamsohn IA. The role of polymorphonuclear leukocytes in the resistance to cutaneous leishmaniasis. Immunol Lett (1998) 64:145-51. doi:10.1016/S0165-2478(98)00099-6

13. Ribeiro-Gomes FL, Otero AC, Gomes NA, Moniz-De-Souza MC, CysneFinkelstein L, Arnholdt AC, et al. Macrophage interactions with neutrophils regulate Leishmania major infection. J Immunol (2004) 172:4454-62. doi:10. 4049/jimmunol.172.7.4454

14. Tacchini-Cottier F, Zweifel C, Belkaid Y, Mukankundiye C, Vasei M, Launois $\mathrm{P}$, et al. An immunomodulatory function for neutrophils during a $\mathrm{CD}^{+} \mathrm{Th} 2$ response in BALB/c mice infected with Leishmania major. J Immunol (2000) 165:2628-36. doi:10.4049/jimmunol.165.5.2628

15. Novais FO, Santiago RC, Báfica A, Khouri R, Afonso L, Borges VM, et al. Neutrophils and macrophages cooperate in host resistance against Leishmania braziliensis infection. J Immunol (2009) 183:8088-98. doi:10.4049/jimmunol. 0803720

16. Guimarães-Costa AB, Nascimento MT, Froment GS, Soares RP, Morgado FN, Conceição-Silva F, et al. Leishmania amazonensis promastigotes induce and 
are killed by neutrophil extracellular traps. Proc Natl Acad Sci U S A (2009) 106:6748-53. doi:10.1073/pnas.0900226106

17. McFarlane E, Perez C, Charmoy M, Allenbach C, Carter KC, Alexander J, et al. Neutrophils contribute to development of a protective immune response during onset of infection with Leishmania donovani. Infect Immun (2008) 76:532-41. doi:10.1128/IAI.01388-07

18. Pearson RD, Steigbigel RT. Phagocytosis and killing of the protozoan Leishmania donovani by human polymorphonuclear leukocytes. J Immunol (1981) 127:1438-43.

19. Gabriel C, McMaster WR, Girard D, Descoteaux A. Leishmania donovani promastigotes evade the antimicrobial activity of neutrophil extracellular traps. J Immunol (2010) 185:4319-27. doi:10.4049/jimmunol.1000893

20. Aga E, Katschinski DM, van Zandbergen G, Laufs H, Hansen B, Müller K, et al. Inhibition of the spontaneous apoptosis of neutrophil granulocytes by the intracellular parasite Leishmania major. J Immunol (2002) 169:898-905. doi:10.4049/jimmunol.169.2.898

21. Sarkar A, Aga E, Bussmeyer U, Bhattacharyya A, Möller S, Hellberg L, et al. Infection of neutrophil granulocytes with Leishmania major activates ERK 1/2 and modulates multiple apoptotic pathways to inhibit apoptosis. Med Microbiol Immunol (2013) 202:25-35. doi:10.1007/s00430-012-0246-1

22. Gueirard P, Laplante A, Rondeau C, Milon G, Desjardins M. Trafficking of Leishmania donovani promastigotes in non-lytic compartments in neutrophils enables the subsequent transfer of parasites to macrophages. Cell Microbiol (2008) 10:100-11. doi:10.1111/j.1462-5822.2007.01018.x

23. Peters NC, Egen JG, Secundino N, Debrabant A, Kimblin N, Kamhawi S, et al. In vivo imaging reveals an essential role for neutrophils in leishmaniasis transmitted by sand flies. Science (2008) 321:970-4. doi:10.1126/science.1159194

24. Mosser DM, Miles SA. Avoidance of innate immune mechanisms by the protozoan parasite, Leishmania spp. In: Denkers E, Gazzinelli R, editors. Protozoans in Macrophages. Landes Bioscience (2007). p. 118-29.

25. Puentes SM, Dwyer DM, Bates PA, Joiner KA. Binding and release of C3 from Leishmania donovani promastigotes during incubation in normal human serum. J Immunol (1989) 143:3743-9.

26. Hermoso T, Fishelson Z, Becker SI, Hirschberg K, Jaffe CL. Leishmanial protein kinases phosphorylate components of the complement system. EMBO J (1991) 10:4061-7.

27. Brittingham A, Morrison CJ, McMaster WR, McGwire BS, Chang KP, Mosser DM. Role of the Leishmania surface protease gp63 in complement fixation, cell adhesion, and resistance to complement-mediated lysis. J Immunol (1995) 155:3102-11.

28. Cunningham AC. Parasitic adaptive mechanisms in infection by Leishmania. Exp Mol Pathol (2002) 72:132-41. doi:10.1006/exmp.2002.2418

29. Ehlers MR. CR3: a general purpose adhesion-recognition receptor for innate immunity. Microbes Infect (2000) 2:289-94. doi:10.1016/S1286-4579(00) 00299-9

30. Gasque P. Complement: a unique innate immune sensor for danger signals. Mol Immunol (2004) 41:1089-98. doi:10.1016/j.molimm.2004.06.011

31. Holm A, Tejle K, Magnusson KE, Descoteaux A, Rasmusson B. Leishmania donovani lipophosphoglycan causes periphagosomal actin accumulation: correlation with impaired translocation of PKC alpha and defective phagosome maturation. Cell Microbiol (2001) 3:439-47. doi:10.1046/j.1462-5822.2001.00127.x

32. Lerm M, Holm A, Seiron A, Särndahl E, Magnusson KE, Rasmusson B. Leishmania donovani requires functional $\mathrm{Cdc} 42$ and Racl to prevent phagosomal maturation. Infect Immun (2006) 74:2613-8. doi:10.1128/IAI.74.5.2613-2618.2006

33. Scianimanico S, Desrosiers M, Dermine JF, Méresse S, Descoteaux A, Desjardins $M$. Impaired recruitment of the small GTPase rab7 correlates with the inhibition of phagosome maturation by Leishmamnia donovani promastigotes. Cell Microbiol (1999) 1:19-32. doi:10.1046/j.1462-5822.1999.00002.x

34. Lodge R, Descoteaux A. Leishmania donovani induce periphagosomal F-actin accumulation through retention of the GTPase Cdc42. Cell Microbiol (2005) 7:1647-58. doi:10.1111/j.1462-5822.2005.00582.x

35. Vinet AF, Fukuda M, Turco SJ, Descoteaux A. The Leishmania donovani lipophosphoglycan excludes the vesicular proton-ATPase from phagosomes by impairing the recruitment of synaptotagmin V. PLoS Pathog (2009) 5:e1000628. doi:10.1371/journal.ppat.1000628

36. Courret N, Frehel C, Prina E, Lang T, Antoine JC. Kinetics of the intracellular differentiation of Leishmania amazonensis and internalization of host MHC molecules by the intermediate parasite stages. Parasitology (2001) 122:263-79. doi:10.1017/S0031182001007387
37. Fruth U, Solioz N, Louis JA. Leishmania major interferes with antigen presentation by infected macrophages. J Immunol (1993) 150:1857-64.

38. Kwan WC, McMaster WR, Wong N, Reiner NE. Inhibition of expression of major histocompatibility complex class II molecules in macrophages infected with Leishmania donovani occurs at the level of gene transcription via a cyclic AMP-independent mechanism. Infect Immun (1992) 60:2115-20.

39. Thi EP, Lambertz U, Reiner NE. Sleeping with the enemy: how intracellular pathogens cope with a macrophage lifestyle. PLoS Pathog (2012) 8:e1002551. doi:10.1371/journal.ppat.1002551

40. Cameron P, McGachy A, Anderson M, Paul A, Coombs GH, Mottram JC, et al. Inhibition of lipopolysaccharides-induced macrophage IL-12 production by Leishmania mexicana amastigotes: the role of cysteine peptidase and the NF-kappaB signalling pathway. J Immunol (2004) 173:3297-304. doi:10.4049/ jimmunol.173.5.3297

41. Gantt KR, Schultz-Cherry S, Rodriguez N, Jeronimo SM, Nascimento ET, Goldman TL, et al. Activation of TGF- $\beta$ by Leishmania chagasi: importance for parasite survival in macrophages. J Immunol (2003) 170:2613-20. doi:10.4049/ jimmunol.170.5.2613

42. Kima PE. The amastigote forms of Leishmania are experts at exploiting host cell processes to establish infection and persist. Int J Parasitol (2007) 37:1087-96. doi:10.1016/j.ijpara.2007.04.007

43. Singh S, Sivakumar R. Challenges and new discoveries in the treatment of leishmaniasis. JInfect Chemother (2004) 10:307-15. doi:10.1007/s10156-004-0348-9

44. Monzote L. Current treatment of leishmaniasis: a review. Open Antimicrob Agents J (2009) 1:9-19.

45. Richard JV, Werbovetz KA. New antileishmanial candidates and lead compounds. Curr Opin Chem Biol (2010) 14:447-55. doi:10.1016/j.cbpa.2010. 03.023

46. Buates S, Matlashewski G. Treatment of experimental leishmaniasis with the immunomodulators imiquimod and S-28463: efficacy and mode of action. J Infect Dis (1999) 179:1485-94. doi:10.1086/314782

47. Arevalo I, Ward B, Miller R, Meng TC, Najar E, Alvarez E, et al. Successful treatment of drug-resistant cutaneous leishmaniasis in humans by use of imiquimod, an immunomodulator. Clin Infect Dis (2001) 33:1847-51. doi:10.1086/324161

48. Miranda-Verastegui C, Lianos-Cuentas A, Arevalo I, Ward BJ, Matlashewski G. Randomized, double-blind clinical trial of topical imiquimod 5\% with parenteral meglumine antmoniate in the treatment of cutaneous leishmaniasis in Peru. Clin Infect Dis (2005) 40:1395-403. doi:10.1086/429238

49. Al-Mulla Hummadi YM, Najim RA, Al-Bashir NM. Leishmania major and Leishmania tropica: I the in vitro effects of an immunomodulator, S2-complex. Exp Parasitol (2005) 111:47-54. doi:10.1016/j.exppara.2005.04.007

50. Nahrevanian H, Jalalian M, Farahmand M, Assmar M, Rastaghi AE, Sayyah M. Inhibition of murine systemic leishmaniasis by acetyl salicylic acid via nitric oxide immunomodulation. Iran J Parasitol (2012) 7:21-8.

51. Mukherjee S, Ukil A, Das PK. Immunomodulatory peptide from cystatin, a natural cysteine protease inhibitor, against leishmaniasis as a model macrophage disease. Antimicrob Agents Chemother (2007) 51:1700-7. doi:10.1128/AAC 01555-06

52. Shukla S, Bajpai VK, Kim M. Plants as potential sources of natural immunomodulators. Rev Environ Sci Biotechnol (2014) 13:17-33. doi:10.1007/s11157-0129303-x

53. Patwardhan B, Gautam M. Botanical immunodrugs: scope and opportunities. Drug Discov Today (2005) 10:495-502. doi:10.1016/S1359-6446(04)03357-4

54. Sachdeva H, Sehgal R, Kaur S. Asparagus racemosus ameliorates cisplatin induced toxicities and augments its antileishmanial activity by immunomodulation in vivo. Parasitol Int (2014) 63:21-30. doi:10.1016/j.parint.2013.09.016

55. Gamboa-Leon R, Vera-Ku M, Peraza-Sanchez SR, Ku-chulim C, Horta-Baas A, Rosado-Vallado M. Antileishmanial activity of a mixture of Tridax procumbens and Allium sativum in mice. Parasite (2014) 21:15. doi:10.1051/parasite/2014016

56. Adriazola IO, Amaral AE, Amorim JC, Correia BL, Petkowicz CL, Mercê AL, et al. Macrophages activation and leishmanial activity by galactomannan and its oxovanadium (IV/V) complex in vitro. J Inorg Biochem (2014) 132:45-51. doi:10.1016/j.jinorgbio.2013.09.017

57. Néris PL, Caldas JP, Rodrigues YK, Amorim FM, Leite JA, RodriguesMascarenhas S, et al. Neolignan Licarin A presents effect against Leishmania (Leishmania) major associated with immunomodulation in vitro. Exp Parasitol (2013) 135:307-13. doi:10.1016/j.exppara.2013.07.007

58. Chowdhury S, Mukherjee T, Mukhopadhyay R, Mukherjee B, Sengupta S, Chattopadhyay S, et al. The lignan niranthin poisons Leishmania donovani 
topoisomerase IB and favours a Th1 immune response in mice. EMBO Mol Med (2012) 4:1126-43. doi:10.1002/emmm.201201316

59. Saha P, Bhattacharjee S, Sarkar A, Manna A, Majumder S, Chatterjee M. Berberine chloride mediates its anti-leishmanial activity via differential regulation of the mitogen activated proteinkinase pathway in macrophages. PLoS One (2011) 6:e18467. doi:10.1371/journal.pone.0018467

60. Shakya N, Sane SA, Gupta S. Antileishmanial efficacy of fluconazole and miltefosine in combination with an immunomodulator picroliv. Parasitol Res (2011) 108:793-800. doi:10.1007/s00436-010-2230-2

61. Dos Santos RA, Batista J Jr, Rosa SI, Torquato HF, Bassi CL, Ribeiro TA, et al. Leishmanicidal effect of Spiranthera odoratissima (Rutaceae) and its isolated alkaloid skimmianine occurs by a nitric oxide dependent mechanism. Parasitology (2011) 138:1224-33. doi:10.1017/S0031182011001168

62. Hosseini N, Abolhassani M. Immunomodulatory properties of borage (Echium amoenum) on Balb/c mice infected with Leishmania major. J Clin Immunol (2011) 31:465-71. doi:10.1007/s10875-010-9502-6

63. Gharavi M, Nobakht M, Khademvatan S, Bandani E, Bakhshayesh M, Roozbehani M. The effect of garlic extract on expression of INF- $\gamma$ and iNOS genes in macrophages infected with Leishmania major. Iran J Parasitol (2011) 6:74-81.

64. Gharavi M, Nobakht M, Khademvatan S, Fani F, Bakhshayesh M, Roozbehani M. The effect of aqueous garlic extract on interleukin-12 and 10 levels in Leishmania major (MRHO/IR/75/ER) infected macrophages. Iran J Public Health (2011) 40:105-11.

65. Sen R, Ganguly S, Saha P, Chatterjee M. Efficacy of artemisinin in experimental visceral leishmaniasis. Int J Antimicrob Agents (2010) 36:43-9. doi:10.1016/j. ijantimicag.2010.03.008

66. Gomes DC, Muzitano MF, Costa SS, Rossi-Bergmann B. Effectiveness of the immunomodulatory extract of Kalanchoe pinnata against murine visceral leishmaniasis. Parasitology (2010) 137:613-8. doi:10.1017/S0031182009991405

67. Githinji EK, Irungu LW, Tonui WK, Rukunga GM, Mutai C, Muthaura CN, et al. In vitro effects of Warburgia ugandensis, Psiadia punctulata and Chasmanthera dependes on Leishmania major promastigotes. Afr J Tradit Complement Altern Med (2010) 7:264-75.

68. Soares DC, Andrade AL, Delorenzi JC, Silva JR, Freire-de-Lima L, Falcão CA, et al. Leishmanicidal activity of Himatanthus sucuuba latex against Leishmania amazonensis. Parasitol Int (2010) 59:173-7. doi:10.1016/j.parint.2010.01.002

69. Wabwoba BW, Anjili CO, Ngeiywa MM, Ngure PK, Kingondu EM, Ingonga J, et al. Experimental chemotherapy with Allium sativum (Liliaceae) methanolic extract in rodents infected with Leishmania major and Leishmania donovani. J Vector Borne Dis (2010) 47:160-7.

70. López R, Cuca LE, Delgado G. Antileishmanial and immunomodulatory activity of Xylopia discreta. Parasite Immunol (2009) 31:623-30. doi:10.1111/j.13653024.2009.01134.x

71. Bhattacharjee S, Gupta G, Bhattacharya P, Mukherjee A, Mujumdar SB, Pal A, et al. Quassin alters the immunological patterns of murine macrophages through generation of nitric oxide to exert antileishmanial activity. J Antimicrob Chemother (2008) 63:317-24. doi:10.1093/jac/dkn479

72. Gamboa-León MR, Aranda-González I, Mut-Martín M, García-Miss MR, Dumonteil E. In vivo and in vitro control of Leishmania mexicana due to garlicinduced NO production. Scand J Immunol (2007) 66:508-14. doi:10.1111/j. 1365-3083.2007.02000.x

73. Trun W, Kiderlen AF, Kolodziej H. Nitric oxide synthase and cytokines gene expression analyses in Leishmania-infected RAW 264.7 cells treated with an extract of Pelargonium sidoides (Eps 7630). Phytomedicine (2006) 13:570-5. doi:10.1016/j.phymed.2005.07.004

74. Kolodziej H, Kiderlen AF. Antileishmanial activity and immune modulatory effects of tannins and related compounds on Leishmania parasitised RAW
264.7 cells. Phytochemistry (2005) 66:2056-71. doi:10.1016/j.phytochem.2005. 01.011

75. Mishra PK, Singh N, Ahmad G, Dube A, Maurya R. Glycolipids and other constituents from Desmodium gangeticum with antileishmanial and immunomodulatory activities. Bioorg Med Chem Lett (2005) 15:4543-6. doi:10.1016/j.bmcl. 2005.07.020

76. Pereira WK, Lonardoni MV, Grespan R, Caparroz-Assef SM, Cuman RK, Bersani-Amado CA. Immunomodulatory effect of Canova medication on experimental Leishmania amazonensis infection. J Infect (2005) 51:157-64. doi:10.1016/j.jinf.2004.09.009

77. do Socorro S, Rosa Mdo S, Mendonça-Filho RR, Bizzo HR, de Almeida Rodrigues I, Soares RM, et al. Antileishmanial activity of a linalool-rich essential oil from Croton cajucara. Antimicrob Agents Chemother (2003) 47:1895-901. doi:10.1128/AAC.47.6.1895-1901.2003

78. Ghazanfari T, Hassan ZM, Ebtekar M, Ahmadiani A, Naderi G, Azar A. Garlic induces a shift in cytokine pattern in Leishmania major-infected BALB/c mice. Scand J Immunol (2000) 52:491-5. doi:10.1046/j.1365-3083.2000.00803.x

79. Ukil A, Biswas A, Das T, Das PK. 18 Beta-glycyrrhetinic acid triggers curative Th1 response and nitric oxide up-regulation in experimental visceral leishmaniasis associated with the activation of NF-kappa B. J Immunol (2005) 175:1161-9. doi:10.4049/jimmunol.175.2.1161

80. Trinchieri G. Interleukin-12: a proinflammatory cytokine with immunoregulatory functions that bridge innate resistance and antigen-specific adaptive immunity. Annu Rev Immunol (1995) 13:251-76. doi:10.1146/annurev.iy.13.040195. 001343

81. Munder M, Mallo M, Eichmann K, Modolell M. Murine macrophages secrete interferon gamma upon combined stimulation with interleukin (IL)-12 and IL-18: a novel pathway of autocrine macrophages activation. J Exp Med (1998) 187:2103-8. doi:10.1084/jem.187.12.2103

82. Kane MM, Mosser DM. The role of IL-10 in promoting disease progression in leishmaniasis. J Immunol (2001) 166:1141-7. doi:10.4049/jimmunol.166.2.1141

83. Couper KN, Blount DG, Riley EM. IL-10: the master regulator of immunity to infection. J Immunol (2008) 180:5771-7.

84. Diehl S, Anguita J, Hoffmeyer A, Zapton T, Ihle JN, Fikrig E, et al. Inhibition of Th1 differentiation by IL-6 is mediated by SOCS1. Immunity (2000) 13:805-15. doi:10.1016/S1074-7613(00)00078-9

85. Spelman K, Burns J, Nichols D, Winters N, Ottersberg S, Tenborg M. Modulation of cytokine expression by traditional medicines: a review of herbal immunomodulators. Altern Med Rev (2006) 11:128-50.

Conflict of Interest Statement: The authors declare that the research was conducted in the absence of any commercial or financial relationships that could be construed as a potential conflict of interest.

Received: 05 March 2014; accepted: 18 April 2014; published online: 05 May 2014. Citation: Chouhan G, Islamuddin M, Sahal D and Afrin F (2014) Exploring the role of medicinal plant-based immunomodulators for effective therapy of leishmaniasis. Front. Immunol. 5:193. doi: 10.3389/fimmu.2014.00193

This article was submitted to Immunotherapies and Vaccines, a section of the journal Frontiers in Immunology.

Copyright (C) 2014 Chouhan, Islamuddin, Sahal and Afrin. This is an open-access article distributed under the terms of the Creative Commons Attribution License (CC $B Y)$. The use, distribution or reproduction in other forums is permitted, provided the original author(s) or licensor are credited and that the original publication in this journal is cited, in accordance with accepted academic practice. No use, distribution or reproduction is permitted which does not comply with these terms. 